УДК $330.46(519.766 .4)$

Бідюк П.І.

доктор. техн. наук, професор

Жиров О.Л.

канд. техн. наук, доиент

Трухан C.B.

Жирова А.О.

Національний технічний університет України «КПІ»

\title{
ЗАСТОСУВАННЯ СИСТЕМНОГО ПІДХОДУ ДО МЕНЕДЖМЕНТУ РИЗИКІВ
}

\section{ПРИМЕНЕНИЕ СИСТЕМНОГО ПОДХОДА К МЕНЕДЖМЕНТУ РИСКОВ \\ AUTOMATION OF MULTICRITERION CHOICE OF POTENTIAL SUPPLIER}

У статті запропоновано системний підхід до аналізу фінансових ризиків, зокрема операційних ризиків, які широко розповсюджені у фінансовій системі. Розглянуто задачі інтегрування існуючих елементів системного підходу в єдину методологію аналізу, розглянути деякі існуючі підходи до моделювання операційних ризиків з метою встановлення можливості їх подальшого використання у системах підтримки прийняття рішень відповідного призначення, запропонувати використання ймовірнісних моделей у формі байєсівських мереж для опису операційного ризику. Показано, щуо основними підходами до моделювання ризиків є моделювання розподілів втрат, регресійний аналіз (лінійні та нелінійні моделі), моделі байєсівського типу (регресія та байєсівські мережі) $i$ нечітка логіка. Наведено приклад застосування теорії байєсівських мереж до оиінювання операційного ризику. Перевагою БМ порівняно з іншими математичними моделями для аналізу ризиків є гнучкість до надходження нових даних. Також створена БМ дає можливість оцінити можливі причини втрат, після того як вони мали місце, $і$ швидко реагувати на допущені недоліки функиіонування компанії.

Ключові слова: байєсівські мережі, фінансовий ризик, системний аналіз

В статье предложен системный подход к анализу финансовых рисков, в частности операционных рисков, которые широко распространены в финансовой системе. Рассмотрень задачи интегрирования существующих элементов системного подхода в единую методологию анализа, рассмотрень некоторые существуюшие подходы $\kappa$ моделированию операционных рисков с иелью установления возможности их дальнейшего использования в системах поддержки принятия решений соответствующего назначения, предложено использование вероятностных моделей в форме байесовских сетей для описания операционного риска. Показано, что основными подходами к моделированию рисков является моделирование распределений потерь, регрессионный анализ (линейные и нелинейные модели), модели байесовского типа (регрессия и байесовские сети) $u$ нечеткая логика. Приведен пример применения теории байесовских сетей к оценке операционного риска. Преимуществом БС по сравнению с другими математическими моделями для анализа рисков является гибкость к поступлению новых данных. Также созданная БС дает возможность оченить возможные причины потерь, после того как 
они имели место, и быстро реагировать на допущенные недостатки функционирования компании.

Ключевые слова: байесовские сети, финансовый риск, системный анализ.

The paper studies possibilities for development of systemic approach to analysis of financial risks, especially to operational risks that are widely spread in financial system. We looked into the problem of integration of existing elements into a single system approach analysis methodology. We consider some existing approaches to modelling operational risk in order to establish the possibility of their further use in decision support systems appropriate destination. Using of probabilistic models in the form of Bayesian networks to describe operational risk is offered. The article shown that the basic approaches to risk modelling are description of loss distributions, regression analysis (linear and nonlinear models), Bayesian models (regression and Bayesian networks) and fuzzy logic. An example is given for application of Bayesian network theory to estimation of operational risk. Advantages of the network in comparison to other mathematical models are flexibility to incoming data and possibilities to hiring different types of data in one model. The BN model developed provides a possibility for identification of possible reasons for a loss after it has happened and quickly react to the company functioning drawbacks.

Keywords: Bayesian networks, financial risk, systems analysis.

Вступ. Високоякісний менеджмент ризиків в економіці, фінансах, технічних системах, технологічних процесах та багатьох інших напрямах діяльності - високо актуальна задача, оскільки втрати від недосконалого ризик-менеджменту надзвичайно великі $[1,2]$. Сьогодні існують різні підходи до розв'язання цієї задачі залежно від предметної області. Так, у деяких випадках окремо розглядають задачі аналізу можливих ризиків, що стосуються інформаційних технологій, які використовуються у фінансових організаціях, кредитні та ринкові ризики і т. ін. [3, 4]. Загалом процедура аналізу та менеджменту ризиків складається 3 таких етапів: виявлення ризикових ситуацій; встановлення типу ризику; математичне моделювання ризику і прогнозування можливих наслідків; встановлення необхідних дій стосовно ліквідації ризику або його перенесення на іншу організацію; оцінювання об'єму можливих втрат і реалізація дій стосовно управління поточною ситуацією, що має ознаки настання ризику втрат.

Одним iз ефективних сучасних підходів до менеджменту ризиків $\epsilon$ системний підхід, який передбачає аналіз та врахування можливих невизначеностей, пов'язаних із математичним моделюванням та оцінюванням ризиків; врахування зовнішніх і внутрішніх (частіше випадкових) факторів впливу на діяльність організації; застосування імітаційного моделювання ситуацій; проектування, реалізацію та використання систем підтримки прийняття рішень (СППР) ієрархічного типу 3 метою генерування альтернативних рішень та вибору кращого 3 них за прийнятний час i 3 прийнятною вартістю [5].

Робота присвячена удосконаленню системного підходу до менеджменту 
фінансових ризиків за допомогою СППР, зокрема до аналізу та оцінювання операційних ризиків, які $є$ одними із самих розповсюджених у діяльності фінансових підприємств.

Постановка завдання. Основними задачами цього дослідження $є$ такі: - удосконалення системного підходу до аналізу та менеджменту фінансових ризиків; - інтегрування існуючих елементів системного підходу в єдину методологію аналізу; - розглянути деякі існуючі підходи до моделювання операційних ризиків 3 метою встановлення можливості їх подальшого використання у системах підтримки прийняття рішень відповідного призначення; - запропонувати використання ймовірнісних моделей у формі байєсівських мереж для опису операційного ризику в умовах наявності невизначеності; - навести приклад побудови і застосування байєсівської мережі до оцінювання операційного ризику.

Методологія. У ході проведення дослідження за обраною тематикою були використані такі теоретичні та емпіричні методи наукового пізнання: порівняння, абстрагування, аналіз, синтез та системний підхід.

Результати дослідження. Застосування системного підходу до операційного ризик-менеджменту вимагає застосування методології концептуалізації та операціоналізації ситуацій, пов'язаних 3 настанням ризику. Для цього необхідно визначити необхідні характеристики організації як системи і скористатись ними для розв'язання задачі. Також важливо щоб проектувальник СППР мав необхідні знання з історії систем та їх походження. Таким чином, підхід до застосування загальної теорія систем (ЗТС) до розв'язання задачі менеджменту операційного ризику складається з двох фаз.

1. Отримання знань стосовно ЗТС та реалізації іiі методів через наведені нижче кроки.

- Усвідомлення ідей системного підходу та забезпечення адекватного розуміння функцій всієї системи перед розробленням ії окремих частин.

- Побудова моделей. Достатньо глибоко продумані моделі допоможуть зрозуміти реальність того, що відбувається у компанії. Для побудови математичних моделей та виконання обчислювальних експериментів необхідно використовувати сучасні інформаційні технології, методи теорії оцінювання, статистичного аналізу даних та прийняття рішень.

2. Впровадження СППР у практику використання. Реалізація та використання належної СППР в рамках операціоналізації ризик менеджменту (ОР3) - це, на сьогодні, обов'язок фінансового інституту. Сучасний динамічний системний підхід, який грунтується на множині необхідних елементів, показано на рис. 1 [7]. 


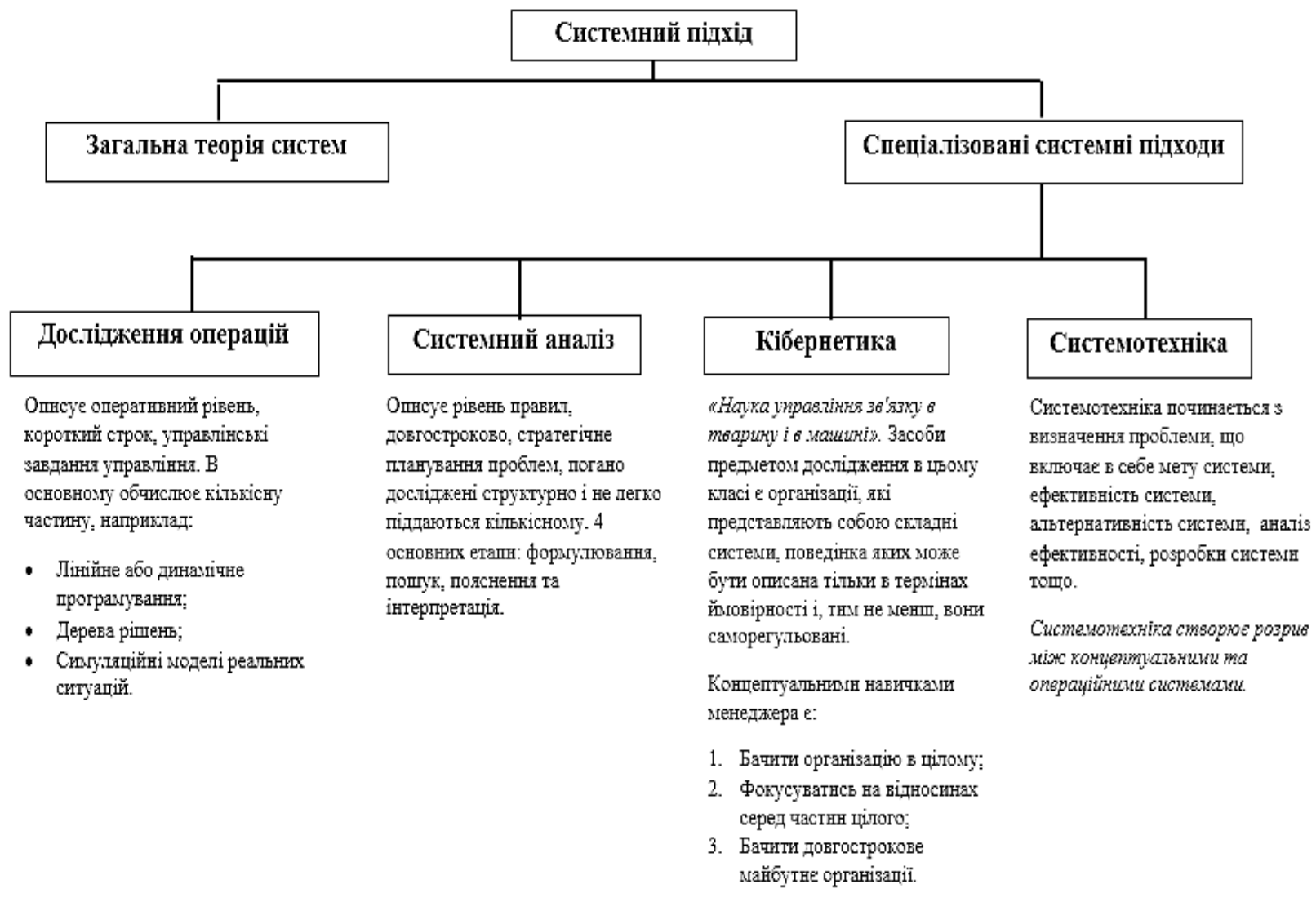

Рис. 1. Загальні складові системного підходу

Розв'язання задачі менеджменту ризиків починається із вивчення загального системного підходу 3 подальшим переходом до конкретних методів: дослідження операцій, системного аналізу, кібернетичних методів, системотехніки та інших. Цей підхід демонструє зростання складності задач та введення необхідності управління відповідними об'єктами організації. Відомо, що зростання складності розв'язуваних задач та їх постановка у динамічному контексті - це необхідні умови для виживання будь-якої системи, а реалізація управління забезпечує виконання умов економічного балансування, необхідних для стійкого зростання.

Системне середовище, що створюється у фінансовій організації, повинне істотно впливати на продуктивність системи у цілому. Це означає, що зростання і регулювання продуктивності системи має бути у рівновазі 3 навколишнім (ринковим) середовищем. Крім того, використання системного поняття холізму означає, що проектувальник СППР повинен починати iз загальної проблематики (постановки задачі дослідження ризиків) і поступово переходити до конкретних рішень стосовно побудови математичних моделей, прогнозування ситуацій i генерування альтернатив. При цьому ризикменеджер повинен планувати наперед дії стосовно менеджменту ризиків та удосконалювати те, що було визначене як задовільне на сьогодні. Отже, моделювання процесів за допомогою СППР спрямовується на надання 
допомоги в аналізі діяльності організації як відкритої органічної системи, що функціонує в умовах постійних змін. Процес створення СППР повинен починатися із загальної концептуалізації запланованої системи та іiі відношення до діяльності організації в цілому.

Після цього у систему можна вводити необхідні обчислювальні процедури (функції) для отримання бажаних кількісних результатів. Системи, що орієнтовані на поглиблені дослідження ризикових ситуацій, повинні включати множину альтернатив для побудови моделей, розташованих у відповідній ієрархії, з метою пошуку задовільної моделі для прийняття рішень стосовно діяльності досліджуваних об'єктів (наприклад, фінансових організацій).

Зв'язаність задач при формулюванні системного підходу. Для того щоб задовольнити вимоги компанії і забезпечити ефективний контроль за менеджментом ризиків необхідно досягти високої ефективності використання СППР, створеної на принципах системного аналізу. Управління операційними ризиками має грунтуватись на переліку функцій і процедур, які виконуються як в рамках і за межами комп'ютерної СППР. Тому процеси управління операційними ризиками у фінансовій організації необхідно розглядати як управління складною багатозв'язаною системою. Це дає можливість зрозуміти, визначити і проаналізувати конкретні типи ризиків, наприклад, супутні проблеми, пов'язані із застосуванням інформаційних технологій (IT) та безпекою обробки даних. Система повинна включати в себе характеристики конкретної організації, виконавців робіт, робочі завдання, характеристики комп'ютерного та програмного забезпечення, необхідні види документації і даних, існуючих у реальному середовищі, включаючи, також, клієнтів інших банків та їх правила. Енстром (Yungström) стверджує, що 3 точки зору безпеки інформації такий підхід являє собою цілісний погляд на менеджмент операційних ризиків [8]. Деякі подробиці структури і методології Енстрома, спрямовані на досягнення інформаційної безпеки на основі впровадження системно-цілісної моделі показані на рис. 2.

Моделі Енстрома [8] засновані на ЗТС, кібернетичних принципах i загальній теорії живих систем (ЗТЖС). Зміст системного модуля, тобто його технічні і нетехнічні аспекти, зображені на рис. 2. ЗТС отримала своє походження та розвиток завдяки довгостроковим довгостроковим спостереженням та дослідженням, як це мало місце у багатьох інших науках.

Але концепція системи тут розглядається як епістемологічний об'єкт (абстракція), що використовується для опису системи, як цілого. Таким чином, Енстром припускає, що системний модуль можна розглядати в якості інструменту пізнання або мета-науки, що використовується для встановлення зв'язку 3 іншими науками. При цьому встановлюються також критерії контролю процесів взаємодії елементів зв'язаних систем. 


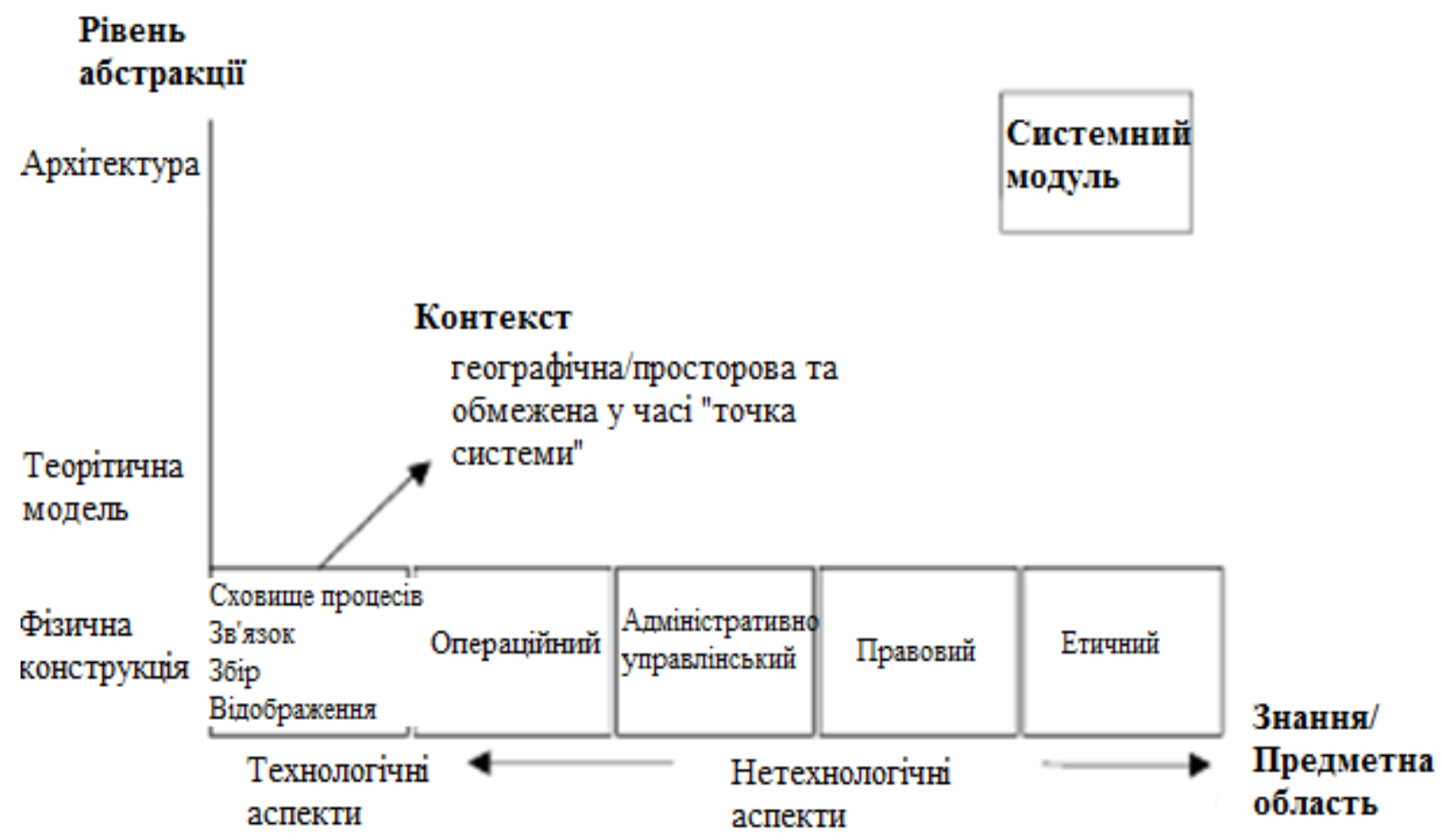

Рис. 2. Інформація про структуру і методологію безпеки інформаційної системи - системно-цілісна модель

Таким чином, можна розглянути та дослідити всю складну систему, яка може включати у якості напрямів діяльності кілька предметних областей, а також необхідні відомості про ці області. Крім того, особлива увага повинна приділятися негативним і позитивним механізмам зворотного зв'язку з метою розуміння балансу, необхідного для стійкого розвитку та управлінням, які $\epsilon$ двома основними функціями, що взаємодіють у системах, які борються за виживання. Весь цей процес управління та контролю функціонування називається системно-цілісним підходом. Однак, коли вводиться управління операційними ризиками і вони досліджуються як елементи загальної системи, то системний модуль повинен вказує на те, що найбільш важливими принципами (елементами) успішного функціонування складних фінансових об'єктів є такі: - об'єкт (організація) активно взаємодіє 3 навколишнім середовищем; - системне середовище створює негативні і позитивні впливи на діяльність організації; - функціонування відбувається в умовах активного накопичення, обробки, використання і пересилання інформації; - структура побудованої системи управління має задовольняти системним принципам іiі побудови та забезпечувати високу якість динамічного управління процесами в організації.

Таким чином, вона повинна справлятися 3 внутрішнім і зовнішнім 
розмаїттям (діяльності) відповідно до закону Ешбі стосовно необхідної різноманітності. Згідно 3 цим законом для досягнення стійкого передбачуваного результату діяльності необхідно щоб функціональна багатогранність керованої системи повинна бути щонайменше такою ж, як і розмаїття їі діяльності, якою необхідно управляти.

Деякі математичні моделі операційних ризиків. Існують два основних підходи до класифікації ризиків - з точки зору чинників (факторів) ризику і з точки зору наслідків дії ризикових подій. Так само моделі можуть бути розділені на два основні класи: моделі, засновані на аналізі наслідків (часто використовується назва: "аналіз зверху вниз" або top down) і моделі, засновані на аналізі чинників ризику (часто використовується назва: "на основі аналізу знизу вверх" або bottom ир).

3 іншого боку, в якості відмінної ознаки моделі може використовуватися множина задач, для розв'язання яких ця модель може використовуватися. Так, моделі, що надають можливість отримати у явному виді функцію розподілу втрат, можуть використовуватися як для оцінювання середніх втрат, так і для оцінювання максимальних втрат на заданому рівні значущості, наприклад, підхід до оцінювання втрат за методологією value-at-risk. В той же час спрощені моделі або моделі, засновані на експертному оцінюванні, не надають можливості отримати чисельні оцінки цих параметрів і можуть бути застосовані лише для вирішення вузького класу задач (табл. 1.). Але спрощені моделі мають переваги, пов'язані 3 простотою їх структури, відносно невеликими обчислювальними витратами, простотою інтерпретації результатів та модифікації.

Моделі, засновані на аналізі наслідків, в більшості своїй використовують апарат математичної статистики. Ця група методів припускає збір і дослідження даних про втрати, зумовлені ОР впродовж передуючих періодів 3 наступною екстраполяцією цих даних на наступні періоди. Найбільш поширеними є такі моделі: BIA (Basic Indicator Approach - метод основних індикаторів); LDA (Loss Distribution Approach - метод розподілу втрат (збитків)); IMA (Internal Measurements Approach - метод внутрішніх вимірів).

Модель BIA описана в Базельській угоді [6], що описує вимоги по забезпеченню достатності капіталу для покриття ризиків. Ця модель була запропонована для вирішення завдання оцінювання максимально можливих втрат від ОР із заданим рівнем значущості (99\%). Вона заснована на припущенні про те, що операційні втрати є залишковими значеннями від загальних втрат, пов'язаних з ризиками (інакше кажучи, за вирахуванням втрат, пов'язаних з іншими типами ризиків). Шуканий квантиль розподілу випадкової величини $x$, що характеризує величину втрат, задається формулою: 


$$
\widehat{Q}_{99 \%}=\overline{G I} \cdot \alpha,
$$

де $\widehat{Q}_{99 \%}$ - оцінка квантиля 99\% випадкової величини, що характеризує втрати (тобто вимоги до капіталу, необхідного для покриття ризику); $\overline{G I}$ - середній валовий дохід за три попередні роки, в яких валовий річний дохід був позитивний; $\alpha=15 \%$ - коефіцієнт, визначений Базельським комітетом на основі дослідження галузевої практики (для банків). Для застосування цієї моделі при оцінюванні ризику страхового шахрайства (СШ) можна розглядати замість валового доходу об'єм нарахованої премії - цей параметр відображає об'єм бізнесу. Проте значення коефіцієнта $\alpha$ для покриття ризику шахрайства необхідно уточнювати 3 використанням результатів оцінювання втрат, пов'язаних 3 ризиком шахрайства, виконаних в декількох українських СК. Недоліком цієї моделі $\epsilon$ те, що отримана оцінка об'єму шахрайства залежатиме тільки від об'єму бізнесу, але не залежатиме від якості контрольних процедур, впроваджених для виявлення випадків шахрайства, а також не залежатиме від особливостей страхового портфеля.

Модель BIA описана в Базельській угоді [6], що описує вимоги по забезпеченню достатності капіталу для покриття ризиків. Ця модель була запропонована для вирішення завдання оцінювання максимально можливих втрат від ОР із заданим рівнем значущості (99\%). Вона заснована на припущенні про те, що операційні втрати є залишковими значеннями від загальних втрат, пов'язаних з ризиками (інакше кажучи, за вирахуванням втрат, пов'язаних з іншими типами ризиків). Шуканий квантиль розподілу випадкової величини $x$, що характеризує величину втрат, задається формулою:

$$
\widehat{Q}_{99 \%}=\overline{G I} \cdot \alpha,
$$

де $\widehat{Q}_{99 \%}$ - оцінка квантиля 99\% випадкової величини, що характеризує втрати (тобто вимоги до капіталу, необхідного для покриття ризику); $\overline{G I}$ - середній валовий дохід за три попередні роки, в яких валовий річний дохід був позитивний; $\alpha=15 \%$ - коефіцієнт, визначений Базельським комітетом на основі дослідження галузевої практики (для банків). Для застосування цієї моделі при оцінюванні ризику страхового шахрайства (СШ) можна розглядати замість валового доходу об'єм нарахованої премії - цей параметр відображає об'єм бізнесу. Проте значення коефіцієнта $\alpha$ для покриття ризику шахрайства необхідно уточнювати 3 використанням результатів оцінювання втрат, пов'язаних з ризиком шахрайства, виконаних в декількох українських СК. Недоліком цієї моделі $є$ те, що отримана оцінка об'єму шахрайства залежатиме тільки від об'єму бізнесу, але не залежатиме від якості контрольних процедур, впроваджених для виявлення випадків шахрайства, а також не залежатиме від особливостей страхового портфеля. 
Класифікація моделей для аналізу і управління ОР

\begin{tabular}{|c|c|c|c|c|}
\hline Клас моделей & $\begin{array}{c}\text { Застосування } \\
\text { для розподілу } \\
\text { ризиків по } \\
\text { групах } \\
\text { критичності }\end{array}$ & $\begin{array}{c}\text { Застосування } \\
\text { для визначення } \\
\text { середніх втрат }\end{array}$ & $\begin{array}{c}\text { Застосування } \\
\text { для визначення } \\
\text { максимально } \\
\text { можливих втрат }\end{array}$ & $\begin{array}{l}\text { Застосування для } \\
\text { виявлення подій, } \\
\text { що ведуть до } \\
\text { реалізації ризику }\end{array}$ \\
\hline \multicolumn{5}{|c|}{ Моделі, основані на аналізі наслідків (Top Down) } \\
\hline BIA & & & + & \\
\hline IMA & & & + & \\
\hline LDA & + & + & + & \\
\hline \multicolumn{5}{|c|}{ Моделі, основані на аналізі факторів ризику (Bottom Up). } \\
\hline Sb-AMA & + & + & + & \\
\hline $\begin{array}{c}\text { Метод } \\
\text { функціональних } \\
\text { кореляцій }\end{array}$ & + & + & + & \\
\hline $\begin{array}{c}\text { Регресійний } \\
\text { аналіз }\end{array}$ & + & + & + & + \\
\hline $\begin{array}{c}\text { Байссівські } \\
\text { мережі }\end{array}$ & + & + & + & + \\
\hline $\begin{array}{c}\text { Методи нечіткої } \\
\text { логіки }\end{array}$ & + & & & + \\
\hline
\end{tabular}

В основі моделей класу LDA лежить припущення про те, що випадкова величина $x$, що характеризує розмір втрат протягом проміжку часу $t$, може бути задана так:

$$
x=\sum_{i=1}^{n(t)} L_{i},
$$

де $n(t)$ - випадкова величина, що характеризує кількість випадків втрат даного типу, що стались протягом періоду $t ; L_{i}-$ множина випадкових величин, що характеризують величини окремих втрат. При цьому робиться припущення, що величини $L_{i}$ незалежні і однаково розподілені для даного типу збитків. Для побудови моделей виконується аналіз втрат за даний період за кожною парою «лінія бізнесу»/«тип втрати». Для кожної такої пари на основі даних про частоту втрат і величину збитків, що спостерігались у минулих періодах, розраховується вибіркове середнє значення частоти виникнення ризикових подій $(E(n(t)))$ і вибіркове середнє значення величини втрат при виникненні ризикової події $(E(L))$.

Далі робиться припущення про тип розподілу випадкових величин $n(t)$ i $L$. На практиці використовуються як стандартні розподіли (наприклад розподіл Пуассона або негативний біноміальний розподіл для моделювання 
частоти збитків), так і емпіричні (тобто функція розподілу будується виключно на основі історичних даних). Для стандартних розподілів, параметри оцінюються на основі історичних даних. Після визначення функцій розподілу випадкових величин $n(t)$ i $L$, будується функція розподілу випадкової величини $x$. Зважаючи на складність побудови цієї функції в явному вигляді, як правило, вона будується за методом Монте-Карло на основі. Після побудови функції розподілу випадкової величини $x$, що характеризує загальний об'єм втрат за цим видом ризиків, можна отримати рішення як задачі точкового оцінювання математичного очікування втрат, так і задачі розрахунку квантиля заданого рівня, що дозволяє розраховувати показники OpVaR (Operational Value at Risk).

Метод IMA дає можливість отримати оцінку максимально можливих втрат для цього виду ризиків без побудови розподілу випадкової величини $x$, що характеризує розмір втрат. В основі цього підходу лежить припущення про те, що якщо розділити усі збитки на очікувані (тобто, в сумі близькі до математичного очікування суми збитків за період) і непередбачені (такі, що перевищують середне і відносяться до "хвоста" статистичного розподілу), то існує функціональна залежність між величинами очікуваних і непередбачених збитків. Простим випадком є лінійна залежність, тобто:

$$
\widehat{Q}_{99 \%}=E I \cdot P E \cdot L G E=\gamma \cdot E L,
$$

де $\hat{Q}_{99 \%}$ - оцінка 99-и процентного квантиля розподілу можливих втрат (величини капіталу, необхідного для покриття ризику) за цим типом події; $P E$ - ймовірність настання негативної події цього типу в даний період; $L G E$ середня величина збитку цього типу за умови настання негативної події; $E I-$ коефіцієнт масштабу; $\gamma-$ коефіцієнт, що дозволяє оцінити вимоги до капіталу через оцінку очікуваних збитків $E L$.

Сукупна оцінка максимально можливих втрат (тобто загальні вимоги до капіталу) визначається шляхом складання усіх оцінок ризику, розрахованих для різних типів ризикових подій i ліній бізнесу. Цей метод можна використовувати для оцінювання ризику СШ, проте заздалегідь необхідно оцінити очікувані втрати, а також розрахувати значення коефіцієнта $\gamma$. Ці розрахунки мають бути зроблені у рамках іншої моделі.

Моделі, що грунтуються на аналізі факторів ризиків, передбачають поглиблений аналіз процесів в організації $\mathrm{i}$ дають можливість використовувати інформацію про внутрішні причинно-наслідкові зв'язки, обумовлені сутністю процесів. В рамках даного класу моделей використовуються різні математичні методи: Sb-AMA (Scenario-based Advanced Measurement Approach - сценарний аналіз); метод функціональних кореляцій; регресійні моделі; Байєсові мережі; методи нечіткої логіки.

Метод Sb-AMA (Scenario-based Advanced Measurement Approach сценарний аналіз), припускає визначення факторів (чинників) ризику (тобто 
можливих джерел виникнення ризиків), на основі яких виконується генерування сценаріїв (за правилом "щзо станеться, якщз ..."). Таким чином, на відміну від описаних вище методів, що припускають аналіз збитків, що сталися, ця модель заснована на оцінюванні можливих втрат, які можуть статися в майбутньому при реалізації деякої події.

Байєсівські мережі дають можливість відобразити в моделі виявлені причинно-наслідкові зв'язки між різними чинниками ризику i змінами середовища[9]. Проте на відміну від регресійних моделей, байєсівські мережі дозволяють враховувати не лише безпосередні залежності рівня ризику від факторів ризику, а також і залежності між факторами ризику. Окрім того, ця група моделей надає більше можливостей для виводу з неповними даними.

3 математичної точки зору БМ - орієнтований граф, де вершинам відповідають чинники ризику і зміни середовища, а ребрам відповідають виявлені або передбачувані взаємозв'язки. Мережа також описується набором умовних розподілів випадкових величин, що характеризують ці чинники ризику і змінні середовища.

Перевагою цього методу $\epsilon$ можливість одночасного використання експертного оцінювання (наприклад, для побудови мережі шляхом визначення залежностей між змінними), і математичних методів (наприклад, для виводу по мережі - розрахунку умовної ймовірності неспостережуваних змінних при заданих значеннях спостережуваних). За рахунок цього модель дозволить зв'язати як наявну вибірку статистичних даних так i експертні знання. У подальшому розглянемо застосування БМ до моделювання операційних ризиків, пов'язаних із шахрайством.

Типи байссівських мереж. Більшість моделей, описаних у другому розділі даної роботи, передбачають виконання аналізу кількості операційних втрат і їх величини окремо. При використанні моделі, основаної на БМ, для ризику СШ доцільно використовувати такий же підхід, оскільки це дозволить спростити модель, а отже, i виконання розрахунків. Виходячи із специфіки поставленої задачі і доступних даних, необхідно побудувати модель, яка дасть можливість для кожного збитку оцінити ймовірність того, що він пов'язаний із шахрайством, і після цього розрахувати для кожного збитку математичне сподівання втрат, зумовлених шахрайством (воно визначається добутком ймовірності наявності шахрайства та суми страхового відшкодування).

3 математичної точки зору для ОР СШ необхідно побудувати умовний розподіл випадкової величини $P\left(f \mid x_{1}, \ldots, x_{n}\right)$, де $F-$ випадкова змінна, що приймає значення на множині $\left\{0, C_{1}, \ldots, C_{k}\right\}(0$ - відповідає відсутності шахрайства, $C_{i}$ відповідають наявності $i$-го типу шахрайства), і $X_{1} \ldots X_{n}$ випадкові змінні, що відповідають доступним для аналізу параметрам збитку[10]. Завдання є спорідненою завданням класифікації, i доцільно розглянути види БМ, що використовуються для вирішення таких завдань. 
«Наївний» байєсівський класифікатор (naiveBayes): вершина $F$ є батьківською вершиною вершин $X_{1} \ldots X_{n}$, між вершинами $X_{1} \ldots X_{n}$ зв'язків немає (тобто $\forall i=1 . . n P A_{i}=\{F\}$ де $P A_{i}-$ множина батьківських вершин $X_{i}$, що означає, що відповідні випадкові величини незалежні при заданому значенні $F$ ). Для того, щоб задати залежності достатньо задати умовні ймовірності $P\left(x_{i} \mid f\right)$, а висновок можна здійснювати за формулою Байєса[10]:

$$
P\left(f \mid x_{1}, \ldots, x_{n}\right)=\frac{P(f) \prod_{i=1}^{n} P\left(x_{i} \mid f\right)}{\sum_{f^{\prime} \in\left\{0, c_{1, \ldots,} C_{k}\right\}} \prod_{i=1}^{n} P\left(x_{i} \mid f^{\prime}\right) .}
$$

«Наївний» байєсівський класифікатор над деревом (Tree Augmented Naive Bayes): вершина $F$ являється батьківською вершиною вершин $X_{1} \ldots X_{n}$, на вершинах $X_{1} \ldots X_{n}$ побудовано дерево (тобто $\forall i=1 . . n P A_{i}=\{F\}$, або $P A_{i}=\left\{F, X_{m_{i}}\right\}$,щоозначає, що крім $F$ укожної з вершин $X_{1} \ldots X_{n}$ може бути не більше однієї батьківської вершини.«Наївний» байєсівський класифікатор над мережею (Network Augmented Naive Bayes): вершина $F \in$ батьківською вершиною вершин $X_{1} \ldots X_{n}$, на вершинах $X_{1} \ldots X_{n}$ побудована мережа (тобто не накладається обмеження на умовну незалежність $X_{1} \ldots X_{n}$ ).

Довільна БМ: знімаються всі обмеження, вершина може бути як батьківською для вершин $X_{1} \ldots X_{n}$, так і вершини $3 X_{1} \ldots X_{n}$ можуть бути батьківськими для $F$.

При формуванні підходу до чисельної оцінки розподілів, необхідно відзначити, що стандартні підходи до навчання БС не застосовні в даній ситуації. Це обумовлено тим, що стандартні підходи припускають наявність навчальної вибірки 3 певним значенням змінної класу. У розглянутій прикладної задачі навчальна вибірка не містить значень змінної класу. Це обумовлено тим, що кількість виявлених фактів шахрайства вкрай мало.

Також, 3 причин відсутності в навчальній вибірці змінної класу, не представляється можливим побудувати емпіричну спільну щільність розподілу всіх змінних, що входять в БМ. Отже, не може використовуватися прямий висновок за формулою Байєса для оцінки ризику СШ.

Методика побудови моделей актуарного ОР, та ОР СШ. Як було зазначено вище, БМ відображає взаємозалежності між різними елементами системи, що моделюється поетапно таким чином: (1) - вибір (формування) переліку вершин БМ; (2) - визначення взаємозв'язків між вершинами мережі графа (створення структури графа); (3) - чисельне оцінювання взаємозв'язків між вершинами - побудова щільностей розподілів змінних.

Теоретично можливі два принципових різних підходи до побудови моделі: - на підставі статистичних даних; - на підставі експертного оцінювання. Однак, застосування першого підходу неможливе у зв'язку з тим, 
що для навчання мережі потрібна інформація про спільний розподіл випадкових величин, відповідних вершин - а оскільки відсутня інформація про раніше виявлені випадки шахрайства (тобто навчальна вибірка), то не всі спільні розподіли можуть бути оцінені. Таким чином, оцінка повинна бути виконана на основі експертного судження. 3 іншого боку, експертне судження не може грунтуватися тільки на досвіді експертів, так як досвід виявлення випадків шахрайства досить малий. Однак експертне судження може бути використано для побудови БМ і зіставлення класів шахрайства та виявлених закономірностей даних.

Перелік вершин для побудови БМ актуарних ОР - співпадає з переліком факторів ризику, але в умовах неповноти даних деякі фактори потрібно групувати по напрямку їх впливу і будується на основі карти ризиків.

Загальний підхід до побудови моделі оцінки ризику СШ може бути заснований на аналізі характеристик страхових випадків, доступних для аналізу. При формуванні переліку вершин доцільно вводити в модель вершини відповідні тільки тим параметрам, дані по яких доступні для аналізу i які тяжіють до певних значень при реалізації конкретних сценаріїв шахрайства.

Дані про страхувальника можуть вводитися в модель в тих випадках, коли $\epsilon$ можливість звірки $з$ додатковими джерелами інформації («чорними списками»), або коли є можливість створення «профілю зловмисника».

Дані про об'єкт страхування також мають значення, так як тип об'єкта страхування визначає можливість фальсифікації збитку або спотворення інформації про реальну вартість об'єкта. Також грає істотну роль вартість об'єкта страхування, так як реалізація шахрайства для об'єктів 3 низькою вартістю може бути недостатньо прибуткова для зловмисників, а при страхуванні та врегулювання збитків по об'єктах 3 високою вартістю страховиками проводиться велика кількість перевірок, які ускладнюють здійснення всіх дій, необхідних для реалізації шахрайства, що добре відомо зловмисникам.

Дані про договір страхування представляють інтерес, так як, по-перше, для деяких сценаріїв шахрайства буде характерно заяву збитків на ранніх термінах (при страхуванні раніше пошкоджених об'єктів), i, по-друге, цінові параметри договору (в тому числі, параметри впливають на ціну, наприклад, наявність франшизи) є визначальними для шахрая при прийнятті рішення про доцільність реалізації запланованих дій.

Дані про збиток повинні включатися в модель в тому обсязі, в якому вони можуть дати характеристику обставин його виникнення. Наприклад, дата виникнення збитку важлива, так як спільно з датою страхування вона дозволяє визначити термін, що пройшов між укладанням договору та виникненням збитку. Власне тип збитку впливає на легкість його фальсифікації. Нарешті, 
важливу роль відіграє наявність можливості регресного позову до винуватця збитку - при наявності шахрайства така можливість менш імовірна, так як при iï наявності зловмисник має можливість не ускладнювати схему шахрайства шляхом залучення страхової компанії, а отримати кошти з третьої сторони, стосовно якої страховик отримує можливість регресного позову. Нарешті, дані про врегулювання збитку повинні відображатися в моделі у вигляді індикаторної змінної, значення якої відповідають основним формам відшкодування шкоди - натуральної та грошової (грошова форма є більш кращою в разі шахрайства, тому що дозволяє отримати кошти швидше).

При побудові графа необхідно визначити природні взаємозв'язки між змінними моделі. Для частини параметрів такі зв'язки є очевидними. Для частини параметрів такі зв'язки мають бути відсутні.

Перша група зв'язків буде спостерігатися між характеристиками страхувальника та об'єкта страхування. Для роздрібних видів страхування можна припустити, що чим старше страхувальник, тим вище, в середньому, повинна бути вартість об'єкта страхування. Для корпоративних такий зв'язок також має місце, також може спостерігатися зв'язок між загальним розміром активів страхувальника і вартістю даного застрахованого об'єкта.

Друга група зв'язків може мати місце між параметрами об'єкту страхування і характеристиками збитку - чим вище вартість об'єкта, тим вище сума збитку. Одночасно з цим характеристики страхувальника не повинні впливати безпосередньо на характеристики збитку (тільки опосередковано через характеристики об'єкта).

Дані про договір страхування можуть мати взаємозв'язок з параметрами збитку тільки в частині покриття ризиків (зв'язок з типом страхової події) і в частині наявності франшизи (зв'язок із сумою збитку). При цьому терміни укладання договору і виникнення збитку не повинні бути пов'язані (якщо не вважати зв'язком те, що збиток відбувається протягом терміну дії договору страхування - збиток може відбуватися в будь-який момент часу протягом терміну дії договору з рівною ймовірністю).

Дані про форму врегулювання можуть мати природну зв'язок з типом збитку, тому що для деяких типів шкоди натуральна форма відшкодування неможлива або не застосовується на практиці.

Після включення в модель всіх вершин, відповідних параметрам 3 перерахованих груп даних, а також відображення природних зв'язків між ними, потрібне виконання заключного кроку. Модель доповнюється індикаторної змінної, значення якої визначає наявність шахрайства. Далі в модель включаються зв'язки між вершиною, відповідної цієї змінної, та іншими змінними моделі, які можуть тяжіти до певних значень при наявності шахрайства (дане питання мав бути розглянутий при формуванні переліку змінних для включення в модель). 
Побудова моделі актуарного операційного ризику. У роботі «Occasional Paper 20» для London Working Group of EU представлено близько 50 спільних ризиків, які загрожують платоспроможності СК. При цьому сформульовано висновок, що ризики пов'язані через причинні ланцюги. Це привело до розробки групою причинно-наслідкових карт ризику, як практичного інструменту для надання допомоги в аналізі тематичних досліджень. Хоча $є$ багато інших способів класифікації ризиків, причини і наслідки, дозволяють виділити корінь (суть) проблем компанії, і оцінити як відносну важливість причин, так їх кінцевий вплив (рис. 3).

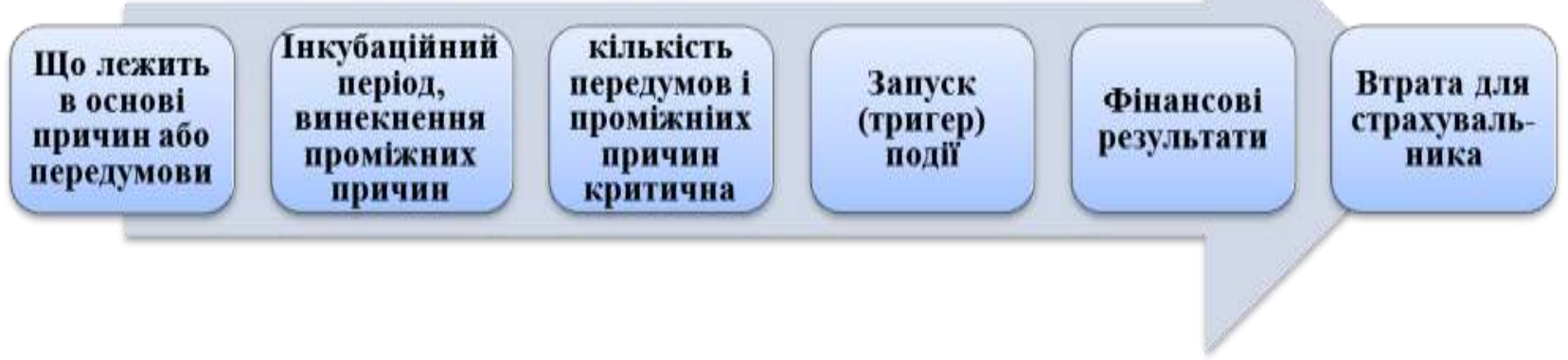

Рис. 3. Причинно-наслідкове відображення процесу утворення операційного ризику СК

Для побудови карти ризиків СК проводиться детальний аналіз, який включає в себе схему компанії, історію, структуру (дочірні підприємства), географію, структуру управління, напрями діяльності (які види страхування).

Причинно-наслідкові відображення ризику використовуються у багатьох сферах і галузях: автомобільній діагностиці, медичній діагностиці, управлінні навколишнім середовищем, на ринку фінансових послуг, а слідом за ним використовувати причинне моделювання почав і ринок страхових послуг. Причинно-наслідкові відображення ризику використовуються у Великобританії і $\mathrm{CC}$, для регулювання можливих причин «невдач» СК, це дозволяє визначити ризики, які загрожують платоспроможності компанії, і як взаємодіють в окремих випадках за допомогою карт ризику (рис.4).

В картах ризику завжди потрібно визначити «тригер подію» - подію яка запускає процес втрат, або несприятливих моментів. Але така подія не являє собою загрозу, лише в поєднанні з проміжними причинами - станами створює проблему. Це зазвичай відбувається у чутливих до зовнішніх факторів СК, з операційною нестабільністю. Це говорить про те, що такі компанії більш схильні до невдачі, ніж ті, в яких не має цих недоліків. Тобто можна припустити, що фірми можуть проявляти «Схильність до втрат». Це означає, що якщо ми можемо визначати ці вразливі місця фірм i, можливо, виправити схильність, то ми зможемо звести задачу мінімізації втрат в наслідок негативних подій. 


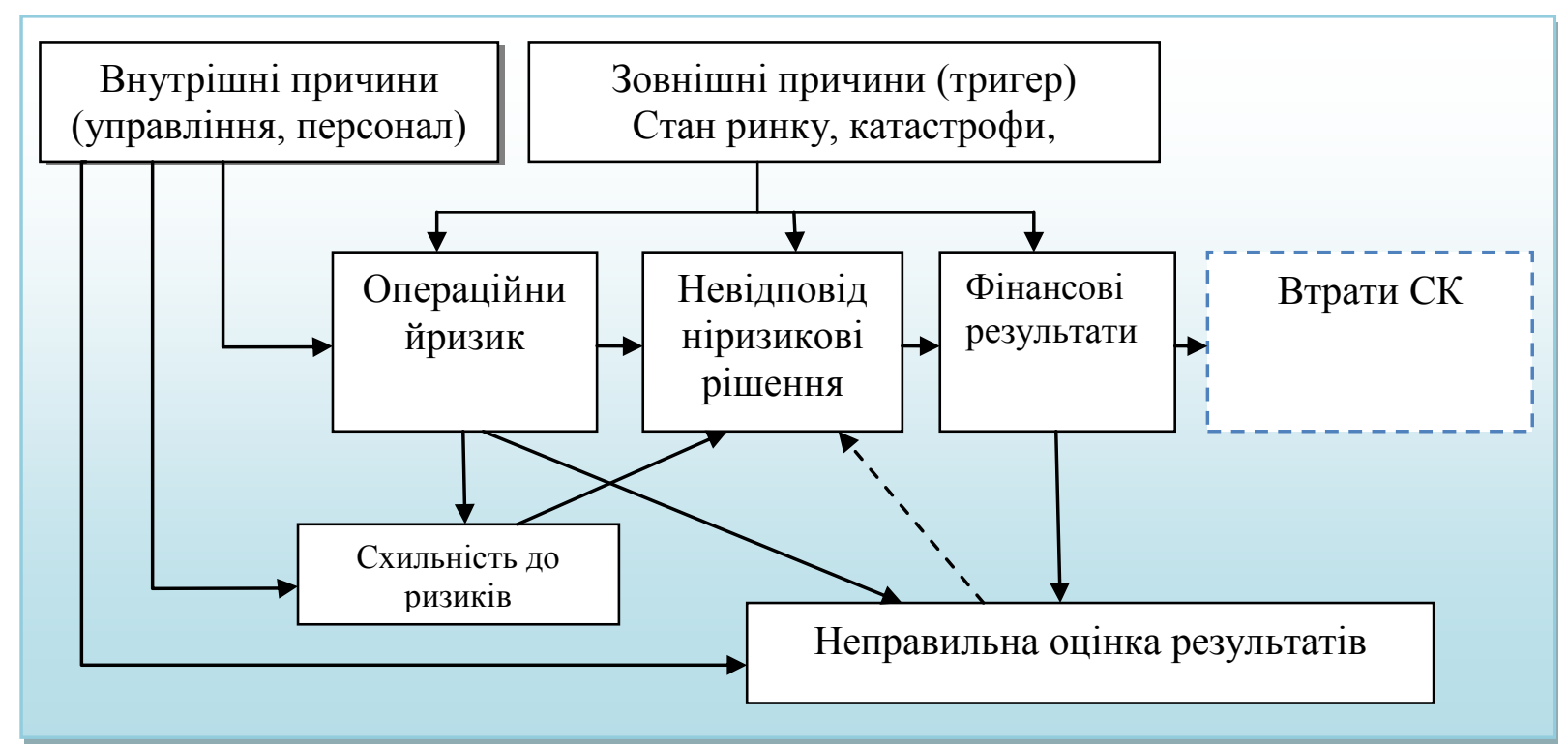

Рис. 4. Карта ризиків СК

Погане управління може привести безпосередньо до неадекватних внутрішніх процесів і систем, що в свою чергу, призведе до недоречних ризикових рішень. Якщо несприятливі змінити в ситуації соціальної та економічної ситуації повинні були відбутися після того, як страховик зробив деякі невірні рішення ризику, страховик цілком може потрапити в серйозні труднощі. Тобто ризики, які у нас були спочатку визначені виявилися проміжними ланками у великому причинно-наслідковому ланцюзі. Хоча можна виділити загальні причини та загальні відносини між причинами, на практиці не існує двох причинних ланцюгів.

В якості вхідних даних для побудови моделі аналізу актуарних ОР СК використовуємо експертні оцінювання діяльності однієї СК. Всі змінні даної мережі характеризують стан конкретної частини СК, або об'єктів що впливають на її діяльність (табл. 2).

Таблиця 2

\section{Вершини БМ для оцінки актуарного ОР}

\begin{tabular}{|l|l|l|}
\hline Назва вершини & Опис & Множина значень \\
\hline Управління & $\begin{array}{l}\text { Внутрішній показник діяльності, який } \\
\text { характеризує управління СК на всіх } \\
\text { рівнях (дочірні, філіали) }\end{array}$ & $\begin{array}{l}\text { “"resilient”, } \\
\text { "normal”, } \\
\text { "inadequate”\} }\end{array}$ \\
\hline $\begin{array}{l}\text { Кваліфікація } \\
\text { персоналу }\end{array}$ & $\begin{array}{l}\text { Внутрішній показник діяльності, який } \\
\text { характеризує освіту, навики, досвід, } \\
\text { культуру персоналу }\end{array}$ & $\begin{array}{l}\text { “"resilient”, } \\
\text { "normal”, } \\
\text { "inadequate”\} }\end{array}$ \\
\hline $\begin{array}{l}\text { Операційні } \\
\text { процедури }\end{array}$ & $\begin{array}{l}\text { Внутрішній показник діяльності, який } \\
\text { характеризує наявність контрольних } \\
\text { процедур, і процеси пов'язані з }\end{array}$ & $\begin{array}{l}\text { “"resilient”, } \\
\text { "normal”, } \\
\text { "inadequate”\} }\end{array}$ \\
\hline
\end{tabular}




\begin{tabular}{|c|c|c|}
\hline & $\begin{array}{l}\text { забезпеченням стабільної діяльності } \\
\text { СК }\end{array}$ & \\
\hline Технології & $\begin{array}{l}\text { Внутрішній показник діяльності, який } \\
\text { характеризує } \\
\text { технологій, методів, принцистів для } \\
\text { вдосконалення робочого процесу }\end{array}$ & $\begin{array}{l}\text { \{“resilient", } \\
\text { "normal", } \\
\text { "inadequate"\} }\end{array}$ \\
\hline Стан СК & $\begin{array}{l}\text { Якісна характеристика, що відбиває } \\
\text { чутливість СК, стабільність, їі роботу }\end{array}$ & $\begin{array}{l}\text { \{"robust", } \\
\text { "adequate", } \\
\text { "disaster"\} }\end{array}$ \\
\hline Стан економіки & $\begin{array}{l}\text { Зовнішній показник, описує стан } \\
\text { економіки, } \\
\text { правового законодавства і т.д. }\end{array}$ & $\begin{array}{l}\text { \{"positive", "neutral", } \\
\text { "adverse"\} }\end{array}$ \\
\hline Шахрайство & $\begin{array}{lccc}\text { Зовнішній } & \text { показник, } & \text { вказує } & \text { на } \\
\text { наявність страхового шахрайства } & \\
\end{array}$ & $\begin{array}{l}\text { \{“light", } \\
\text { "medium", "strong"\} }\end{array}$ \\
\hline Системні збої & $\begin{array}{ll}\text { Зовнішній } & \text { показник, описує системні } \\
\text { збої, } & \text { природні } \\
\text { екстремальні події } & \text { катастрофи, }\end{array}$ & $\{$ “rarely", "neutral", "often"\} \\
\hline Стан НC & $\begin{array}{l}\text { Якісна характеристика, що відбиває } \\
\text { стан НС }\end{array}$ & $\begin{array}{l}\text { \{"robust", "adequate", } \\
\text { "disaster"\} }\end{array}$ \\
\hline Прийняті рішення & $\begin{array}{l}\text { Схильність до прийняття ризику в } \\
\text { залежності від стану СК і впливу НС }\end{array}$ & $\begin{array}{l}\text { \{"riskaverse", "balanced", } \\
\text { "excessive"\} }\end{array}$ \\
\hline $\begin{array}{l}\text { Ймовірність } \\
\text { втрати СК }\end{array}$ & $\begin{array}{l}\text { Ймовірність втрат } \text { СК } \\
\text { репутація...) } \\
\text { в в баланс, } \\
\text { прийнятого рішення }\end{array}$ & $\begin{array}{l}\text { \{“surpluses", } \\
\text { "typical", } \\
\text { "disaster"\} }\end{array}$ \\
\hline
\end{tabular}

БМ будується на основі карти ризиків - аналізу причинно-наслідкових зв'язків, історії СК, аналізу основних процесів СК, оцінки факторів ризику (рис. 5). 


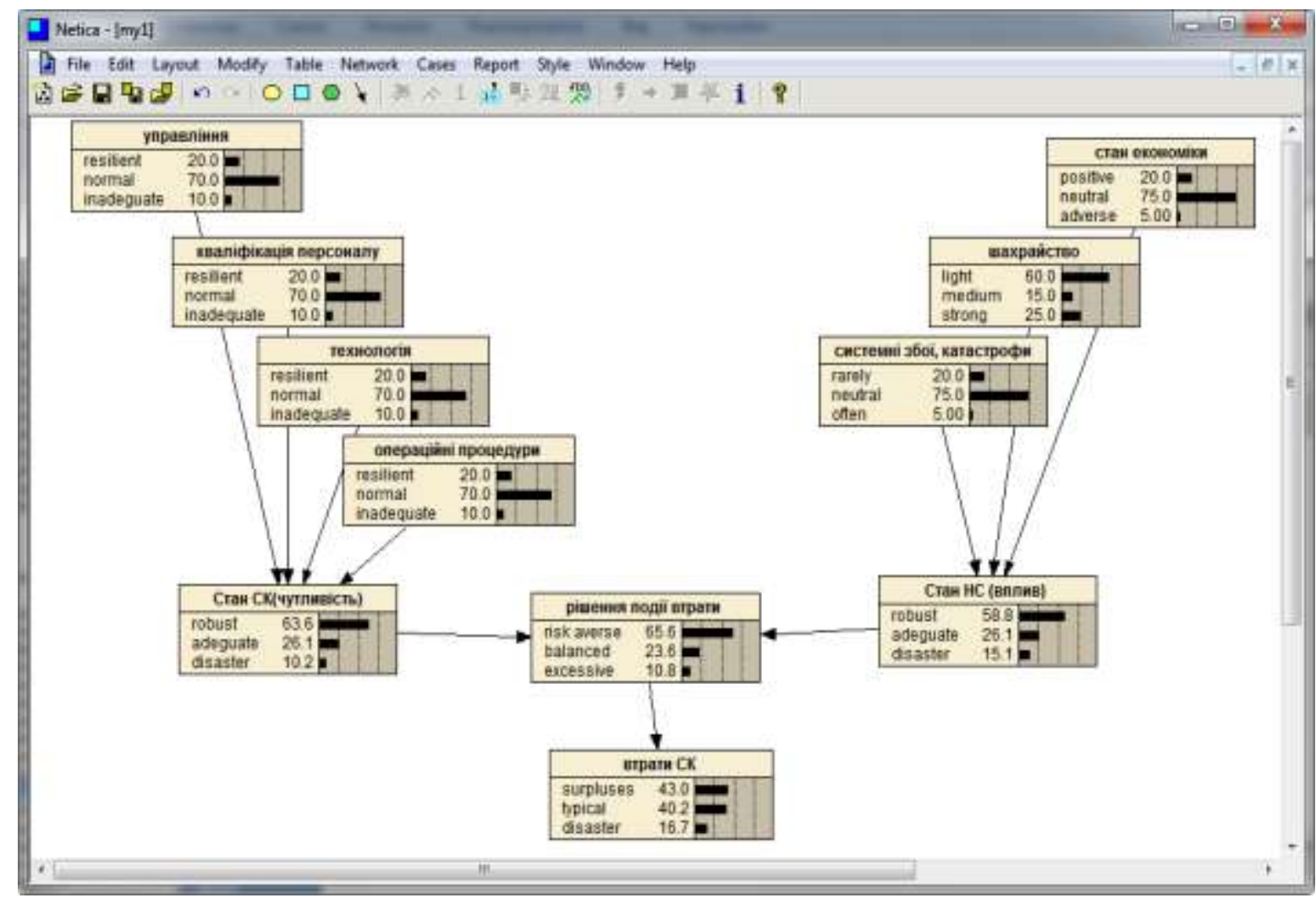

Рис. 5. Байєсівська мережа для аналізу актуарних OP (NETICA)

Основне призначення даної мережі - аналіз втрат СК в наслідок неадекватного управління операційними ризиками. Але завдяки структурі даної мережі, іiі можна використовувати також для аналізу внутрішнього стану СК - знаходити слабкі місця в діяльності даної СК, тобто блок «стан СК

(чутливість)» може використовуватись як індикатор для визначення можливих проблемних областей. Також будова даної мережі дозволяє оцінити стабільність стану НС, зрозуміло, що на умови НС СК не вплине, але в залежності від них можна регулювати діяльність СК, використовувати дану мережу для прийняття рішень. Великою перевагою БМ, в порівнянні з іншими математичними моделями для аналізу ОР, є гнучкість до надходження нових даних. Також дана БМ, дозволяє оцінити можливі причини втрат, після того як вони стались, і швидко реагувати на недоліки.

Висновки. Запропоновано системний підхід до аналізу фінансових ризиків, зокрема операційних ризиків, які широко розповсюджені у фінансовій системі. Елементами системного підходу $є$ адекватний аналіз функціонування фінансового підприємства; виявлення негативних впливів (збурень) на його функціонування; ідентифікація та математичний опис можливих невизначеностей, що впливають на підприємство; розробка та застосування математичних моделей ризиків та їх застосування для 
оцінювання та менеджменту ризиків; вибір (або вироблення) множин статистичних критеріїв якості для контролю процесу моделювання та оцінювання ризику.

Показано, що основними підходами до моделювання ризиків $є$ моделювання розподілів втрат, регресійний аналіз (лінійні та нелінійні моделі), моделі байєсівського типу (регресія та байєсівські мережі) і нечітка логіка. Застосування більшості методів моделювання пов'язане з необхідністю ідентифікації та математичного опису невизначеностей структурного, стохастичного і параметричного типів.

Наведено приклад застосування теорії байєсівських мереж до оцінювання операційного ризику. Основне призначення побудованої мережі аналіз втрат страхової компанії внаслідок неадекватного менеджменту операційними ризиками. Її можна використовувати також для аналізу внутрішнього стану СК - знаходити слабкі місця в їі діяльності, тобто блок «стан СК (чутливість)» може використовуватись як індикатор для визначення можливих проблемних областей. Перевагою БМ, у порівнянні 3 іншими математичними моделями для аналізу ОР, є гнучкість до надходження нових даних. Також створена БМ дає можливість оцінити можливі причини втрат, після того як вони мали місце, і швидко реагувати на допущені недоліки функціонування компанії.

У подальших дослідженнях доцільно розширити номенклатуру моделей, які застосовуються до опису операційних ризиків та створити спеціалізовану систему підтримки прийняття рішень для дослідження операційних ризиків та їх менеджменту.

\section{Література:}

1. Вовчак О.Д. Страхова справа / О.Д. Вовчак - К.: Знання, 2011. - 391 с.

2. Александрова М.М. Страхування / М.М. Александрова:- К.:ЦУЛ, $2002-208$ с.

3. Парасюк I.M. Трансформаційний підхід типу «модель - модель» для реалізації байєсівських механізмів інтелектуального аналізу даних / І.М. Парасюк, С.В. Єршов, О.А. Алексєєнко // Проблеми програмування. 2006, № 2 - 3. Спеціальний випуск. - С. $12-16$.

4. Долгошея Н. О. Страхування в запитаннях та відповідях / Н.О. Долгошея - К.: Центр учбової літератури, 2010. - $318 \mathrm{c}$.

5. Бідюк П.І. Комп’ютерні системи підтримки прийняття рішень / П.І. Бідюк, О.П. Гожий, Л.О. Коршевнюк - Миколаїв: Чорноморський державний університет ім. Петра Могили, 2012. - 380 с.

6. The Bank for International Settlements (BIS), Basel Committee on Banking Supervision, Quantitative Impact, Study 3, Technical Guidance, October 2002.

7. Schoderbek P.P. Management Systems: Conceptual Considerations. / P.P. Schoderbek, C.G. Schoderbek, A.G. Kefalas - New York: Irwin Inc. Company, Custom Publishing, USA, 1990. -280 p. 
8. Yungström L.A. System-Holistic Approach to Academic Programmes in ITSecurity, Ph.D. Thesis, Department of Computer and Systems Science,University of Stockholm and the Royal Institute of Technology, Stockholm, 1996.

9. Балашова Н. Управление операционным риском - аналіз современных тенденций / Н. Балашова // Рынок ценных бумаг. - 2001. - №7 (190) . - С. 68-70.

10. Korb K.B. Bayesian artificial intelligence/ K.B. Korb, A.E. Nicholson - New York: Chapman \& Hall/CRC, 2004. - 365 p. 